\title{
Disturbing the Balance - Woody Allen Reads Dostoyevsky
}

\author{
Michal Bobrowski \\ Uniwersytet Jagielloński, Wydział Zarzadzania i Komunikacji Społecznej, \\ ul. Łojasiewicza 4, 30-384 Kraków, mch.bobrowski@gmail.com
}

\begin{abstract}
Esej je namenjen polemični medbesedilni korespondenci, ki se pojavlja med dramo Woodyja Allena Zločini in prekrški ter romanom Fjodorja Dostojevskega Bratje Karamazovi. V okviru primerjalne analize avtor predstavlja semantične in strukturne podobnosti med obema deloma, hkrati pa opozarja na bistvene svetovnonazorske razlike. Tematika moralnih posledic zavrnitve vere, ki jo je Dostojevski predstavil s perspektive vernika pravoslavne cerkve, je postala za Allena izhodiščna točka za razmišljanje o eksistencialni osamljenosti človeka.
\end{abstract}

This paper discusses the polemic, intertextual correspondence which occurs between Woody Allen's drama Crimes and Misdemeanors and Fyodor Dostoyevsky's novel The Brothers Karamazov. Through a comparative analysis, the author reveals structural analogies between both works, but also fundamental ideological differences. Dostoyevky's approach to the subject of the moral consequences of rejection of religious faith was that of a follower of the Orthodox faith. For Allen, a similar topic became the pretext for deliberations on man's existential solitude.

Ključne besede: medbesedilna polemika, pravoslavna vera, ateizem, religiozna etika, sekularna etika

Key words: Intertextual polemic, Orthodox faith, atheism, religious ethics, secular ethics

Professor Gabriel Roth, the main character in Woody Allen's Husbands and Wives (1990), who is a writer and an academic, describes his attitude towards the work of the great Russian novelists with the following "culinary" metaphor: Tolstoy is a full meal, Turgenev is a fabulous dessert. Dostoyevsky is a full meal with a vitamin pill and extra wheat germ. The latter description is similar to that delivered by André Gide in one of his many lectures devoted to the novels of Fyodor Dostoyevsky: There is a great deal of psychology, sociology 
and moralizing, writes Gide, Dostoyevsky embraced all this, but most of all he remained a superb novelist (Gide 1997: 72). Most critics agree that the author of Notes from the Underground often neglected the purely literary qualities of esthetics; his dramaturgy tends to be disorganized and lacks compositional equilibrium. Colin Wilson, the author of the acclaimed study The Outsider, compared the composition of Dostoyevsky's novels to a pillowcase stuffed with lumps of cement (Wilson 1959: 285). However, this radical opinion should be complemented with the words of Sergei Bulgakov. There is no doubt, writes the Russian scholar, that the majority of Dostoyevsky's novels is guilty of serious negligences, or even carelessness about the composition, hence the indignation of the formalists. However, it feels strange and awkward to speak about the formal inadvertences of such a masterpiece as Brothers Karamazov (Bulgakov 2002: 152). It seems to be widely acknowledged that the esthetic shortcomings of Dostoyevsky's novels are, to some extent, "justified" by the polyphonic outlook of the philosophical tensions and ethical contrasts, artistically aggravated within a truly monumental scale, or - as Woody Allen put it - by the vitamin pills and wheat germ.

Through a comparison of Allen's films with Dostoyevsky's novels, one can trace several distinct analogies. I am aware that this statement might be considered as somewhat unsubstantiated. After all, Dostoyevsky was a writer and thinker strongly devoted to Russian Orthodoxy, while Allen is a Jewish comedian-intellectual attached to secular art and philosophy; it might seem, therefore, that significant parallels between these two artists should not exist. First of all, it is necessary to point out that the intertextual references to Dostoyevsky's threads and motifs are present mostly in Allen's serious films: dramas influenced by the cinema of Ingmar Bergman, like Interiors (1978), September (1987) and Another Woman (1988) or tragicomedies, such as Hannah and Her Sisters (1986), Crimes and Misdemeanors (1989), Husbands and Wives, Deconstructing Harry (1997) and Match Point (2005). The majority of these movies met with a rather unenthusiastic reception from both the critics and the audience, who expected Allen's films to be as light and pleasant as Annie Hall (1977). His non-comedies tend to be pessimistic, disturbing, sometimes even persistent in revealing dark sides of human personality, hidden flaws, vices and anxieties.

In relation to Dostoyevsky's novel, Colin Wilson created a term "the realism of the soul". The Russian writer penetrated the deepest and darkest abyss of the human psyche with the most profound sympathy and sensitivity. What determines Dostoyevsky's genius is the capacity for multifaceted perception of psychological problems. He described human beings as weak creatures, doomed to suffer the existential tragedy of being doubled. Dostoyevsky's world is seized by ethical, ontological and psychological contradictions. All of his greatest characters are ambiguous, often repulsed by the discovery of their own inner monstrosity.

The strong moral and religious beliefs present in Dostoyevsky's prose serve as a counterpoise to his pessimistic outlook on the human condition. This is 
the essence of what André Gide called "moralizing". His visibly pejorative expression precisely describes the didactic aspect of Dostoyevsky's novels, an aspect which is often quite importunate and biased. For the writer himself, the moral teachings contained in his work were at least as important as its esthetic value. In this respect, the analogy with Woody Allen becomes indirect. Instead of moralizing, the filmmaker serves the attitude that might be called "negative moralizing". Avoiding straightforward presentations of positive role models, he prefers to expose and criticize amoral urges and behaviors. In the celluloid restaurant of Woody Allen, the viewer will not be provided with any vitamins or sprouts, but he will receive a meal with a large quantity of cholesterol and artificial preservatives, followed by a lecture on the harmful effects of unhealthy nutrition.

\section{Implied Dissonance}

Obviously, an essay thus limited in size is insufficient to fully exhaust the subject of the intertextual correspondence between Dostoyevsky's books and Allen's films. In order to avoid generalities, it has been necessary to reduce the comparative material. The subsequent part of the article is an analysis of a dialogue between one selected novel by Fyodor Dostoyevsky (The Brothers Karamazov) and one film by Woody Allen (Crimes and Misdemeanors). The goal will be not only to find the parallels that connect these two works, but also to capture essential differences between them and, consequently, to describe their polemical relation.

Among Allen's films, Crimes and Misdemeanors is undoubtedly the one with the deepest roots in Dostoyevsky's prose; at the same time it is probably the most outstanding of the director's serious films. Although the title evidently refers to Crime and Punishment, it is my opinion that Allen's film remains closer to The Brothers Karamazov $v^{l}$ in theme and spirit. In his last masterpiece, Dostoyevsky managed to embrace a holistic outlook as well as to grasp the essence of his ontological and ethical views. He confronted the perspective of a mystical faith from an angle of an intellectual skepticism and analyzed the ethical consequences of these standpoints. The famous quotation stating that Anything is permissible if there is no God, which had appeared before in the socio-politically focused The Devils, became a conceptual core of The Brothers Karamazov, more than any other Dostoyevsky novel. As Colin Wilson points out, in spite of commonly established opinion, Crime and Punishment is not a study of atheism and the idea of absolute freedom. In contrast to other Dostoyevsky nihilists, such as Nikolai Stavrogin or Ivan Karamazov, Rodion Raskolnikov claims to be a believer, though his faith is dynamic and unstable.

${ }^{1}$ It is worth pointing out that originally the film was meant to be titled The Brothers, but it appeared that this title had been already reserved for another movie. 
The title of Crimes and Misdemeanors, as in the case of Allen's comedy Love and Death, refers to a pattern common in classic literature, of titles combining two opposites such as Crime and Punishment, War and Peace, Fathers and Sons, The Red and the Black. According to this style, the two antagonisms ought to be in some way symmetrical, in order to uphold the balance between two scales depending on the conjunction "and". There is an obvious lack of such balance in the title of Crimes and Misdemeanors. This first disturbance anticipates a number of subsequent discords present on various levels of Allen's film. The director tells the story of an unpunished crime. Anything is permissible if there is no God, said Dostoyevsky. But isn't it true that actually everything is permissible?, asks Allen with his movie.

The narrative structure of Crimes and Misdemeanors is patterned on the multilayered plots of Dostoyevsky novels like The Devils and The Brothers Karamazov. Instead of the domination of one main protagonist, Allen unfolds equivalent threads for several characters. For this discussion, the most significant thread is that dealing with Judah Rosenthal (played by Martin Landau). He is a well-situated, respected citizen of his community, a husband, father and a sought-after ophthalmologist. He was raised in the spirit of the Hebrew faith, but later became an atheist. Judah's brother Jack (Jerry Orbach) is connected to the criminal underworld. Recently Judah started a love affair with a stewardess, Dolores (Anjelica Huston). At some point his organized and pleasant life begins to break apart. His problems start in a trivial way, almost like in a soap-opera. The mistress, deluded by his false promises, demands that he divorce his wife. She blackmails him, not only with threats not only to reveal their relationship but also to expose Judah's misappropriation of funds, committed during fundraising for building a new hospital ward. In a moment of crisis Judah turns to his shady brother Jack. They both reject the idea of intimidating the woman as ineffective. There is only one definitive solution - murder. The decision is made and executed.

In the sixth book of The Brothers Karamazov titled The Russian Monk, the holy elder Zosima on his deathbed tells the story of his life to young Alyosha Karamazov. Among many other episodes, there is one with a particularly important function in the semantic structure of the whole novel, as it forecasts and mirrors the key events of the following chapters. This episode is also significant on account of its similarities with the story of Judah Rosenthal. Zosima tells the story of Mikhail, who killed his mistress and went unpunished (Dostoyevsky 1990: 301-313). The blame was placed on the innocent servant of the victim. Mikhail continued to be a respected member of his community.

Up until this moment the story is almost identical to Judah Rosenthal's. The differences lie in the reactions of the perpetrators to their deeds. Mikhail carried a burden of guilt, which caused moral and psychological pain beyond his endurance. The poor wretch started a family, lived as honestly as he could and even tried to appease his conscience with charity. It was all in vain. Finally, after a dozen years, partly because of Zosima, Mikhail felt an irrepressible urge to put an end to his suffering. The alternative was suicide or a purifying, 
public confession. After a difficult inner struggle, he decided on the latter. What is important is that Mikhail had an unshaken conviction that mankind is essentially good, able to build a future paradise on earth, and, above all, he strongly believed in God. With his characteristic remarkable perceptiveness, Dostoyevsky portrayed the contorted psychology of a murderer, showing how the profoundly latent need for redemption remained deaf to the reasoning that the goodness that I caused later indemnifies the evil that I had done and that the consequences of my confession will destroy the lives of my innocent family.

Judah is not a believer; however, he also feels the burden of a guilty conscience. For a while it even seems that it is too heavy for him to carry. Admittedly, the viewer does not know how Judah's story will end, but the last scene suggests that he finally suppresses his guilty conscience and gets back to his previously happy life of a decent family man, the husband, the father and the golf companion. Through Judah's story, Allen shows that there are no objective reasons to claim that the murder wasn't as good a way of dealing with the troublesome situation as any other sufficient method. After all, it turned out to be a hundred percent effective. Does that not mean that everything is permissible?

The greatest characters created by Dostoyevsky are characterized by an extraordinary psychological complexity, wide enough to embrace an entire spectrum of contradictions. They do not fit within the society of ordinary people. Their constitutions are constantly torn apart by conflicting forces, which remain simultaneous even though mutually exclusive. They can contemplate such depths of belief and disbelief at the same moment that sometimes it really seems that they are within a hair's-breadth of being 'turned upside down' ... (Dostoyevsky 1990: 645). Dostoyevsky's protagonists insistently attempt to achieve a state of inner unification. Their restless natures force them to absolute dedication to the ideas with which they identify. This applies both to characters whose beliefs are similar to those worshipped by the writer himself (Alyosha, Zosima or Prince Myshkin) as well as to those whose views of the fundamental questions are diametrically different (Ivan, Raskolnikov or Stavrogin). As Bohdan Urbankowski points out, Dostoyevsky attributes to his characters ideologies that often transform into unbearable burdens (See: Urbankowski 1978: 116).

In his crucial interpretation of Dostoyevsky's work, Mikhail Bakhtin recognized the polyphony of unsettled, polemical dialogue at the junctions of adverse perspectives oon the individual ideas embodied by characters (See: Bakhtin 1984). Regarding the intertextual relation between The Brothers Karamazov and Crimes and Misdemeanors, the most significant voices in the novel's polyphony are Father Zosima, Alyosha, Ivan and Pavel Smerdyakov. The ideas represented by those characters form a specific spatial structure, within which a certain indiscernible equilibrium is maintained. All four voices, however diversified, are placed at opposing poles of the same ideological axis. Alyosha and Ivan are situated at two opposed but symmetrical positions on the axis. Furthermore, Zosima and Smerdyakov occur on the outermost, but equally counterbalanced positions. To some extent, the structure presented in Crimes and Misdemeanors appears similar. In Allen's movie each of the above-mentioned characters of The 
Brothers Karamazov has a counterpart who represents an analogous dialogical voice. Further comparative analysis will reveal considerable differences in the semantic structures of both works, certain significant shifts made by Allen, which disturbed the balance maintained by Dostoyevsky.

The character of Judah clearly refers to Ivan Karamazov (although later I will point out certain crucial differences between them). Both protagonists reject religion. Although Ivan does not take a definitive stand on the matter of existence or non-existence of God, he rebels against and renounces the world which might or might not be His creation. Ivan embodies the ultimate approach to religious faith, which becomes totally discredited by his nihilistic reasoning. I'm a man of science. I've always been skeptic, but I was raised religiously, says Judah. This statement proves that Judah, just like Ivan, considers faith and reason as two mutually exclusive values. Through cold intellectual calculation, both men reach a conclusion that there are no universal, objective moral principles; thus, everything is allowed. This conviction results in the deaths of people connected with them: Ivan's father Fyodor Pavlovich and Judah's lover Dolores. In both cases the active part in the murder is played by the characters' brothers: Smerdyakov (the alleged illegitimate son of Fyodor Karamazov) and Jack. Both of these characters are personifications of the dark sides of their brothers' personalities. While Dostoyevsky described Smerdyakov as vile and repulsive, Jack seems rather bitter and cynical. Both are unscrupulous enough to put into practice the belief that everything is permissible.

Rabbi Ben, who for many years has been Judah's patient and dear friend, serves as a counterpart of Alyosha Karamazov. Being a man of strong faith, Ben leads philosophical debates with Judah, similar to Alyosha's discussions with Ivan. There's a fundamental difference in the way we view the world-says Ben to Judah - You see it as harsh, empty of values and pitiless. And I couldn't go on living if I didn't feel with all my heart a moral structure with real meaning... and forgiveness... and some kind of higher power. Otherwise there's no basis to know how to live. And I know you well enough to know that a spark of that notion is inside you somewhere too. Ben manages to keep his faith, even though he is faced with the misfortune of losing his sight. Rejecting logic, he believes in a higher point and meaning to human distress. This is reminiscent of Alyosha's faith, which remains unshaken when confronted with the death of the innocent child Ilyusha. It is worth noticing that, to Ivan's "Euclidean" reasoning, the suffering of children becomes the major anti-God argument. Alyosha's unconditional faith overcomes even this most evident logical proof of the world's essential injustice.

The task of assigning a counterpart to the character of Father Zosima is problematic. In a way, Professor Louis Levy (Martin S. Bergmann) - a venerable academic portrayed in a documentary directed by Cliff (Woody Allen) - might be considered Zosima's equivalent. Professor Levy's humanistic philosophy is founded on the affirmation of life and praise of love; therefore, the association with Dostoyevsky's wise Elder seems appropriate. However, in contrast to Zosima, Allen's sage is not a believing man in the religious sense. 
Here lies one of the most important shifts in Allen's polemics. God interests Levy only as an idea; he debates the images of sacrum created by people over the centuries. His intellectual approach to God is that of an anthropologist, not a theologian or a follower. He rejects the idea that the universe is God's reflection. On the contrary, he claims that the world itself is soulless. It is only we, with our capacity to love, that gives meaning to the indifferent universe, he lectures. The closure of Professor Levy's thread strikes the viewer as rather confusing. The thinker, who devoted his life's work to promoting life and love, suddenly commits suicide. The reasons behind his decision remain unknown; the note states only, I have gone out the window.

Immediately after Father Zosima's death, the process of rapid decay starts. The stench of the carcass comes as a shock to the monks and the congregation, since it was believed that the remains of holy men would remain untouched by decomposition. People began to question the purity of Zosima's spirit or even to discern the presence of evil forces. There is a meaningful analogy between these two deaths. In the eyes of people from their environments, Louis Levy and Zosima, die in circumstances that contradict everything for which their life stood. Again however, compared to the novel, in the film the semantic balance is not maintained. In The Brothers Karamazov the ominous odor of Zosima's corpse is counteracted by the mystical vision of Alyosha. The world outlook contained in Crimes and Misdemeanors is devoid of such a counterbalance.

\section{The Devil Comes to Seder}

The major discord in the structure of Allen's movie is bound to Judah Rosenthal's thread. In some ways the character is modeled on Ivan Karamazov, although this parallel is accurate only to some extent. Ivan, one of the most fascinating of Dostoyevsky's characters, is torn apart by elements of reason and conscience. In the essay titled Ivan Karamazov as a philosophical type, Sergei Bulgakov describes him as a man of great mind, passionately sincere, absolutely incapable of false compromise with himself (Bulgakov 2002: 154). His merciless intellect makes him a spiritual relative of Friedrich Nietzsche - nihilist and immoralist. Dostoyevsky, whom Lev Shestov described as the great critic of the reason, used Ivan's example to show the results of radical rationalism. The writer himself believed that there were some levels of human existence on which intellect must yield to irrational faith. Ivan is not unaware of that level. Christ from his poem The Grand Inquisitor "burns the heart" of the Inquisitor (who embodies Ivan's philosophical views) with the symbolic gesture of a kiss. The heart signifies an inborn, irrational conscience that cannot be entirely appeased. Ivan turns out to be unable to put his thoughts into practice. The inner conflict of two opposite forces leads him to the verge of insanity. It is Smerdyakov who has the capacity for absolute immoral actions.

The portentous conversation between Ivan and Smerdyakov, which precedes the patricide, appears vague and ambiguous. The future murderer uses fuzzy 
allusions which become clear to Ivan (as well as to the reader) only when it is revealed that it was Smerdyakov who committed the homicide. After the fatal event Ivan has another three encounters with his half-brother. Smerdyakov becomes more and more aggressive and cruel in realizing Ivan as the indirect perpetrator of the crime. Although Alyosha tries to convince him that he is innocent, Ivan feels an unbearable burden of guilt. This shows how merciless Ivan is in his judgments about himself. In this respect, Judah Rosenthal appears as the opposite of Ivan Karamazov. He also speaks with his brother both before and after the murder. Jack, like Smerdyakov, speaks with ruthless honesty. He foresees Judah's intentions even before he admits them to himself. In contrast to Ivan's situation, Judah's guilt is undoubted. His reaction to the responsibility for murder also differs from Ivan's. Judah insistently tries to put blame on Jack and the hired professional killer.

The reason that Ivan wishes his father's death is also diametrically disparate from Judah's motive. Ivan shocks Alyosha with his cruel comment on the conflict between Fyodor Pavlovich and Dmitri Karamazov: One reptile will devour the other. However, Ivan's unscrupulousness is not caused by passionate hatred of his father but arises from his convictions. He finds Fyodor Pavlovich a spiteful, repulsive and despicable man, who does not deserve to live. However, the nature of this thought is purely theoretical; Ivan is incapable of committing the actual crime. Judah's reasons are far more mundane. He does not want his adultery to jeopardize his well established social position. He cannot find the courage to follow Ben's advice and confess everything to his wife. Moreover, he is afraid that Dolores is willing to expose his financial frauds, which could pose a serious threat to his business. Judah is determined to maintain his image of an honest, respectable and deservedly successful man. The social norms are the sole indicator of Judah's ethics. When he manages to break them and keep it a secret, he doesn't feel guilty about it. He excuses himself by claiming that his love affair has hurt nobody, his marriage is burned out and that he only borrowed, not stole, the money for the new hospital ward. When Judah sees the danger of revealing his secret, he decides to break the major rule of social conduct. However deeply instilled, the principle "Thou shall not kill" remains for Jack merely a social norm.

The chapter titled, The Devil: Ivan's Nightmare, is crucial for understanding the character of Ivan Karamazov. It is a record of his argument with the devil, which occurs in the tormented mind of the protagonist after Smerdyakov's last visit. You are my hallucination. You are the incarnation of myself, but only of one side of me... of my thoughts and feelings, but only the nastiest and stupidest of them (Dostoyevsky1990: 637), says Ivan about his infernal guest. The Devil, on account of whom Ivan gained the appellation of the "Russian Faust", personifies all his doubts and dithers. This small chapter, in which Dostoyevsky had his highest artistic achievement, complements the equally magnificent The Grand Inquisitor. A parallel introspective sequence can be found in Crimes and Misdemeanors. Right after the murder, Judah visits the house that used to be his childhood home. This oneiric sequence strongly departs from the realist 
esthetic of the rest of the film. As in the chapter from Dostoyevsky's novel, Judah's inner vision transforms to reality. Judah in his present form travels back in time and becomes a witness to and even a participant in a family Seder dinner, similar to those he remembers. The table conversation becomes an ideological argument. Rabbi Sol, a man of strong religious belief, states that the axiom God punishes the wicked is indisputable. Sol's adversary in the dispute is Aunt Mae - a Marxist and suffragette who clearly refuses to deal with any "opium for the people". She perceives Sol's faith as absurd and counters it with an argument that she considers as evident logical proof of the unsoundness of Sol's conviction. Like Hitler? asks Aunt Mae, Six million Jews burned to death and he got away with it! Mae, a cynic and a nihilist, draws the conclusion that there is no higher justice in the universe: For those who want morality, there is morality, but nothing is handed down in stone. Sol's line of argument remains helpless when confronted with this cold, truly Karamazovian disquisition, for his faith is irrational. Sol's kind of faith is a gift. He believes and you can use logic on him all day long and he still believes, says one of the female guests. Must everything be logical? asks the irritated Sol. At this point Judah, who until now has listened to the discussion in silence, joins the conversation: And if a man commits a crime? If he kills? he inquires. In one way or another he will be punished. Whether it's the Old Testament or Shakespeare, murder will out, answers Sol. If he can do it and get away with it and he chooses not to be bothered by the ethics, he's home free, argues Aunt Mae.

Although this sequence is not a direct transposition of the chapter The Devil, it raises similar ethical and ontological issues. It is worth pointing out that Ivan's devil projects his inner conflict between nihilistic reasoning and the innate sense of higher meaning and absolute morality. In contrast, Judah's moral stands are determined only by his upbringing; therefore, though deeply rooted, they are not a substantial component of his nature. The thread of Judah's religious education runs through the entire film in the form of flashbacks that show him performing Hebrew rituals. I challenged it [the Hebrew background] even as a child, but some of that feeling must have stuck with me, states Judah.

It takes Judah a couple of months to convince himself that it is possible to go on with his life. Right after the murder his conscience is so guilt-ridden that he considers turning himself in. He even denies all his convictions, stating that he believes in God, because without God, the world is a cesspool. But one morning Judah wakes up without guilt. Soon he loses interest in the subject of pointless existence in a world deprived of God. Emptiness is no longer a painful experience; once again it becomes an abstract problem that Judah can discuss with Ben. Judah, like Alex in the final scene of Stanley Kubrick's Clockwork Orange (1971), has cured himself of artificially instilled ethical values.

Henryk Paprocki noticed that names of Dostoyevsky's characters often carry symbolic, biblical meanings (See: Paprocki 1997). This approach could also be applied to Crimes and Misdemeanors. There is an obvious association with Judah's name. In Christian tradition, Judas is an archetype of falsity: the apostle who sold his God. Judah Rosenthal also in some way trades God for his com- 
fortable, bourgeois life. God is luxury I can't afford, claims Judah, indicating that faith has a price. As is generally known, Judas hanged himself. It is interesting that, in The Brothers Karamazov, Smerdyakov, who committed murder for mercenary reasons, took his own life using the same method. Apparently Judah's name links him indirectly to the character of Smerdyakov. This might be interpreted as a suggestion that, although seemingly Judah's character is related to Ivan, in fact he has more in common with the atrocious Smerdyakov.

All the great Dostoyevsky outsiders and nihilists - Raskolnikov, Stavrogin and Ivan Karamazov - commit or consider committing crime as a way to achieve certain philosophical extremes. Judah's acts are driven by entirely different needs. He is a person devoid of higher ideas, essentially mediocre, filled with Smerdyakov-like filth. While in the novel the anxious spirit of Ivan overcomes the shadow side of his personality represented by Smerdyakov, in the film those two stances become united, which ultimately equals the supremacy of Smerdyakov's corruption.

Apart from Judah's rejection of the ethical code, he is not reminiscent of Nietzsche's superman in any respect. He sums up the qualities of a small, weak, cowardly man. In contrast to Dostoyevsky's outsiders, he is an extreme conformist. Allen shows that, if there is no God, then everything is permissible not only to supermen but also to the mediocre who, deprived of vertical morality, become even more terrifying. Even Smerdyakov killed himself; thus, he must have been haunted by feelings of guilt. Judah would be unable to make an attempt on his life.

The semantic structure of The Brothers Karamazov is not limited to the already-presented axis of characters-ideas that connects Zosima, Alyosha, Ivan and Smerdyakov. There is also a second important axis of passionate characters, involving Fyodor Pavlovich, Dmitri Karamazov and Grushenka. A similar axis is present in Crimes and Misdemeanors and relates to the characters of Lester Cliff (Alan Alda) and Halley (Mia Farrow). In both cases the relations between the characters are based on the model of a love triangle, where two men compete for the favors of a woman. This thread is not essential for this article, but it must be at least recognized - otherwise the view of the film would remain incomplete. Cliff is a sensitive and sympathetic man, who tries to act according to his coherent ethical code. Unfortunately, he is also a loser who has not accomplished anything meaningful. Cliff is fascinated by the philosophy of Louis Levy and desires to direct a documentary about him. He admires the classical Hollywood cinema, which seems to have a soothing effect on his troubled soul. He has built a warm relation with his niece, with whom he watches dozens of old, black and white movies. Cliff is in love with Halley - an intelligent and ambitious woman who shares his enthusiasm for Professor Levy. In order to obtain funds for his project, Cliff has to make a film about Lester.

Lester is a successful television producer, a well known and respected figure. He treats people like objects and tends to be self-righteous. Cliff sees him as a primitive, shallow individual who uses double morality. In his movie Cliff synchronizes fragments of recorded interviews with Lester with sampled foot- 
age showing Benito Mussolini as well as Mister Ed, the talking horse from the popular American TV series. Consequently, the project is taken away from him. As is often the case in Allen's films, the joke serves as a vehicle for important meanings. It corresponds with the cynical opinions on the impunity of war criminals in a world deprived of God and absolute morality. Lester could be Judah's younger brother. While Judah commits a crime, Lester's deeds may be described as misdemeanors, but they are both equally internally empty, completely determined by social relations. Unfortunately, both characters win in the end.

Socrates, who is thought to be a precursor of the philosophy of existence, taught that the inner voice of daemonic sign is a force that drives man to virtue. Leaving aside the esthetic and epistemological significance of Socrates' concept of virtue, it might be said that the Greek philosopher saw an inner human moral fibre as a reflection of transcendence. This opinion can be expressed in the sentence, "Not all is allowed, because there is a higher being". Dostoyevsky, however distrustful of logical answers to ultimate questions, behaved like a mathematician who tests correctness of a calculation by performing the adverse operation. He multiplied both sides of the equation by minus one; therefore, what had originally been "There is a God = Not everything is allowed" changed into "God does not exist = Everything is permissible". Dostoyevsky attributed this view to his characters. In order to prove the correctness of Socrates' original equation, he doomed them to failure. Here lies the reason that every attempt at achieving absolute freedom from moral boundaries leads in his novels to a miserable end.

Woody Allen tells the story of a man who managed to win the battle with his daemonic sign. Judah becomes Nietzsche's immoralist; in any case, he cannot be called a superman. Although the film is deeply inspired by Dostoyevsky's work, its final message is distinctly polemical. Does that mean that Allen, like Jean-Paul Sartre, tried to prove the non-existence of God? Or perhaps he rejected an initial equation of Socrates? What if man's attraction to virtue is not the reflection of a higher power but an immanent element of human psychology? In that case, the debates of Alyosha and Ivan as well as Ben and Judah appear pointless. It is worth observing that Cliff - the character played by the director himself, which always indicates some sort of authorial commentary - is not in any way involved in these disputes. Nevertheless, he may be characterized as a man of strong ethical backbone, who remains faithful to his convictions and is able to build warm relationships with others. It seems that, with the character of Cliff, Allen embodied the following simple message: the ability to differentiate between right and wrong is not determined by the existence or non-existence of the almighty. 


\section{REFERENCES}

André GIDE, 1997: Dostojewski. artykuty i wyktady. Trans. by Karolina Kot. Warszawa.

Colin WILSON, 1959: Outsider. Trans. by Maria Traczewska. Krakow.

Sergei BULGAKOV, 2002: Iwan Karamazow jako typ filozoficzny. Wokót Totstoja $i$ Dostojewskiego. Ed. Janusz Dobieszewski. Trans. by Robert Papieski. Warszawa.

Fyodor DOSTOYEVSKY 1990: The Brothers Karamazov. Trans. by Richard Pevear and Larissa Volokhonsky. New York.

Bohdan URBANKOWSKI, 1978: Dostojewski-dramat humanizmów. Warszawa.

Mikhail BAKHTIN, 1984: Problems of Dostoevsky's Poetics. Trans. by Caryl Emerson. London, Minneapolis.

Henryk PAPROCKI, 1997: Lew i mysz, czyli tajemnica człowieka. Esej o bohaterach Dostojewskiego. Białystok.

\section{RUŠENJE RAVNOVESJA - WOODY ALLEN BERE DOSTOJEVSKEGA}

Woody Allen - režiser, povezan z eksistencialnimi tokovi umetnosti in filozofije - je ljubitelj umetnosti Fjodorja Dostojevskega. Sledovi njegove fascinacije se izražajo predvsem v nekomičnih Allenovih filmih, kot so Interiors (1978), Zločini in prekrški (1989), Match Point (2005). Ta razprava se osredinja na film Zločini in prekrški ter na medbesedilne odnose med omenjenim filmom in zadnjim delom Dostojevskega Bratje Karamazovi. V skladu s konceptom Mihaila Bachtina je za romane Dostojevskega značilna idejna polifonija, njihov filozofski pomen nastaja na stičišču nasprotujočih in protislovnih miselnih stališč in pogledov na svet. Razpon etično-ontoloških vprašanj se v delu Bratje Karamazovi zrcali v idejah štirih protagonistov: starca Zosime, Aljoše Karamazova, Ivana Karamazova in Smerdakova. Ideološke razlike med omenjenimi liki prikazuje celoten spekter odnosov, od mistične religioznosti do amoralnega nihilizma.

Analogna četverica protagonistov, ki predstavljajo določena življenjska stališča, se pojavlja tudi v filmu Zločini in prekrški. Zosima se poistoveti z likom profesorja Lisa Levya, filozofa in antropologa, čigar vodilna misel temelji na humanistični afirmaciji življenja. Lik Aljoše ustreza Rabinu Benuju, ki ohranja vero kljub tragedijam, s katerimi se srečuje. Ivana lahko primerjamo z likom Judyja Rosenthala, ki zavrača vero in sklepa, da objektivnih moralnih pravil ni, Serdakova pa z Jackom - bratom Judyja, ki njegove ideje vpeljuje v življenje.

Bistvena razlika v pogledih Dostojevskega in Allena je v odnosu obeh avtorjev do religije. Dostojevski je bil pravoslavne veroizpovedi - njegovi protagonisti, ki zanikajo obstoj boga in absolutnih moralnih vrednot, so obsojeni na poraz, medtem ko Allen, čigar poglede lahko opredelimo kot eksistencialni agnosticizem, zanika obstoj absolutnega etičnega kodeksa, ki naj bi vsak zločin pripeljal do zaslužene kazni. 